\title{
BIRD AND ARTHROPOD COMMUNITIES IN FRAGMENTED HABITAT OF TERNATE
}

\author{
FADILA TAMNGE*) AND AQSHAN SHADIKIN NURDIN \\ Study Program of Forestry, Faculty of Agriculture, Khairun University \\ Campuss II Gambesi, Jusuf Abdurrahman Street, South Ternate, 97719, Indonesia \\ *Email: fadilatamnge@unkhair.ac.id
}

Accepted December 15, 2020 / Approved September 01, 2021

\begin{abstract}
Habitat loss and fragmentation affect bird communities. Edge area created by fragmentation can affect bird communities through availability of arthropod. The objectives of this study are to examine whether there is any difference in bird diversity and abundance between different plantation types and location between fragments, and to examine if there is any correlation between arthropod and birds. To record Bird community was recorded using point count method with a distant between points $50 \mathrm{~m}$ and a fix radius of $25 \mathrm{~m}$ in each point for 10 minutes observation. Observation points were placed in each of edge and interior habitat of Cocos nucifera plantation and Syzygium cumini plantation. Arthropod sampling was done twice using yellow trap. High bird abundance and richness were recorded in edge habitat. A total of 24 bird species of 18 families and 10 orders of arthropod were identified in the study plots. There is no correlation between arthropod and bird abundance. Based on major diet, 46\% of bird species were insectivores, while 54\% species where other types of eater such as 29\% species were frugivores, $9 \%$ species were nectarivores, and each $4 \%$ of bird species were seabirds, carnivores and scavengers, omnivores, and other bird groups).
\end{abstract}

Key words: arthropod communities, bird communities, fragmentation, Ternate

\section{INTRODUCTION}

Bird is one of the natural resources which has a high value, from the ecological, scientific, economic, recreation, art, and cultural aspects. It is important to conduct a study on birds since it is a good indicator for environmental health and biodiversity (Rombang and Rudyanto, 1999). Considering that bird has a great role in human's life and ecosystem, its presence in an ecosystem needs to be preserved (Arumasari, 1989). Several studies show that the loss of habitat and fragmentation has affected bird community. Peripheral area that is created through fragmentation can influence its life sustainability because micro climate change and availability of arthropod. Ecosystems that are close to each other experience energy flow, nutrition and species going beyond its reciprocal limit. As a consequence, the composition on species, structure, and ecological process of an ecosystem close to the peripheral line of another ecosystem can also change (Murcia, 1995).

Peripheral area does not only border the primary forest with the surrounding ecosystem. Different types of stands create peripheral area. According to Mardiastuti (2015), periphery divides two or more areas with different types of ecosystems, different tree stands in the same or different age plant forest, different succession stages, different disruption, is located on the right and left side of the road dividing the forest area. Ternate Island recorded as an Endemic Bird Area (EBA) number ID 171 (Chan et al., 2004), has several types of habitats such as primary forest, beach forest, old mixed garden, coconut plantation, settlement, and Green Open Space (RTH) that are developed as bird habitats.
Bird and biodiversity conservation in general need to take into account many aspects. Information on detailed bird ecology is very limited on Ternate Island. While natural forests continue to decline, plantations on Ternate Island continue to expand. Therefore, it needs a better function of plantations as conservation areas. Knowledge about the role of garden for birds, including factors that affect the use of birds in the habitats is expected to provide alternative solutions to conserve bird species in garden habitats. The objective of this study is to identify the diversity of species and abundance of birds and arthropod in the two types of habitat and peripheral areas (interior vs. periphery), and to identify the relationship between arthropod and bird abundance.

\section{RESEARCH METHOD}

This study was conducted in Takome Village, located at $10 \mathrm{~km}$ from Ternate Downtown. This region has several types of habitats such as Tolire lake, coconut plantations (Cocos nucifera), Java plum or locally jamblang (Syzygium cumini) stands and old mixed gardens. Data collection was carried out in October 2020 and observations were conducted in the morning (06.0009.00 WIT). Observations were only performed during the active time when birds are looking for food.

Tools and materials used were 20x50 Nikon binoculars, Canon SX 50IS digital camera, voice recorder, tally sheet, yellow trap, raffia rope, mouse glue trap, 40x60 cm plastic, Field Guide Book for Birds in the Wallacea Region: Sulawesi, Maluku and Nusa Tenggara (Coates and Bishop, 2000), and Arthropod Determination Keybook (Sulthoni et al., 1991). 
Observation plots were placed on interior habitats, that was on jamblang stands and coconut plantations as well as peripheral habitats (transitional area between jamblang stands and coconut plantations) (Figure 1). The length of observation path was $560 \mathrm{~m}$. The gap between observation points was $50 \mathrm{~m}$ and the observation radius was $25 \mathrm{~m}$. The distance of the outermost plot from the road boundary (fragment) was $5 \mathrm{~m}$.

Inventory of bird species used the point count method (Bibby et al., 2000). Observation time for all observed birds, both visually and auditory was 10 minutes, then the next 5 minutes were utilized to move to the next observation point. Identification of bird sounds referred to the xeno canto website and the naming of bird species referred to Sukmantoro et al. (2007). The observations were conducted in the morning for seven times. It was ended when no new species were added. Observations were not carried out on rainy days.

Arthropod inventory was conducted using a yellow trap made of modified plastic. The trap tool was made using a 4-inch diameter Rucika pipe with $40 \mathrm{~cm}$ long. The pipe was painted with Avian yellow paint to attract arthropod. The pipe was then wrapped in clear plastic and coated with mouse glue trap as an arthropod adhesive. Insect traps were placed under the canopy at each observation point which was adjusted to the number of bird observation plots (Figure 2). The arthropod traps were checked once for three days. Arthropod were identified up to family level.

Diversity index is a mathematical illustration to facilitate information analysis about the number of individuals and the number of species in an area (Magurran, 2004). Furthermore, the relationship between bird and arthropod communities was analyzed using the Pearson correlation test. Pearson correlation is used to measure the strength of the relationship between two variables. The magnitude of the relationship ranges from $0-1$. If it is approaching 1 , it means that the relationship between the two variables is stronger, and vice versa, if it is approaching 0 , it means that the relationship between the two variables is weaker. Pearson correlation was analyzed using SPSS Stat. 25.
Shanon-Wiener Diversity Index formula is as follows:

$$
\begin{gathered}
\quad \mathbf{H}^{\prime}=-\sum \mathbf{p}_{\mathbf{i}} \mathbf{l n} \mathbf{p}_{\mathbf{i}} \\
\text { Description: } \text { H' }^{\prime}=\text { Index of species diversity } \\
\mathrm{Pi}=\text { Proportion of imprtant value } \\
\text { In = Natural logarithm } \\
\text { Equitability (Evenness) Value: } \mathrm{E}=\mathrm{H}^{\prime} / \mathrm{In} \mathrm{S} \\
\text { Description: } \mathrm{E}=\text { Evenness index } \\
\text { H' = Index of species diversity } \\
\text { S = Number of species } \\
\text { In = Natural logarithm }
\end{gathered}
$$

\section{RESULT AND DISCUSSION}

\section{Bird Community}

There were 328 individual birds from 24 species, 22 clan and 18 families. As many as 16 bird species were found on the interior of jamblang stands, 17 species on the interior of coconut plantations and 18 species on the peripheral habitat (Table 1). Based on the observation, the periphery habitat was the study location with the highest number of bird abundances and species richness compared to other habitats (Table 2).

Abundance bird species were found in the peripheral habitats compared to coconut plantations and jamblang stands. Peripheral habitats are characterized by different patterns, types and biodiversity from other habitats (Yoza, 2006). Mulyani et al. (2020) stated that bird abundance is influenced by the peripheral forest area. Periphery can affect bird abundance in a forest fragment through changes in biotic and abiotic conditions (Murcia, 1995). Furthermore, Berry (2001) added that more birds are identified in the peripheral areas as more birds inhabited open habitats. Peripheral habitats have different characteristics compared to other habitat uses, so the inhabiting birds are species that like to live in open areas as well as closed areas. According to Meffe and Carrol (1994), number of species will increase in a productive area.

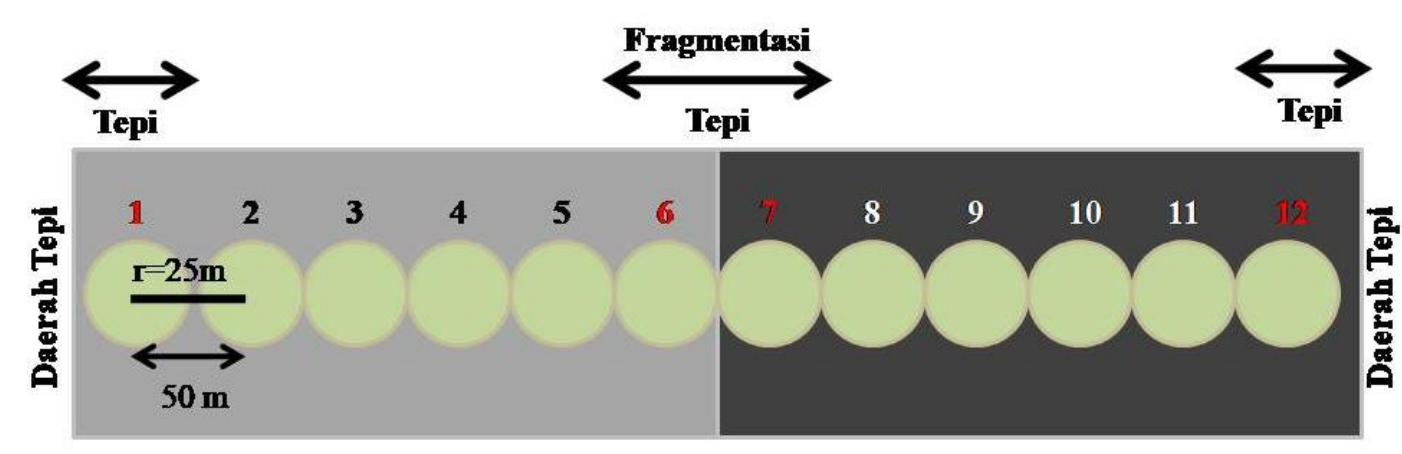

Figure 1. Illustration of bird and arthropod observation plot placement 
Table 1. Bird species composition at three study locations

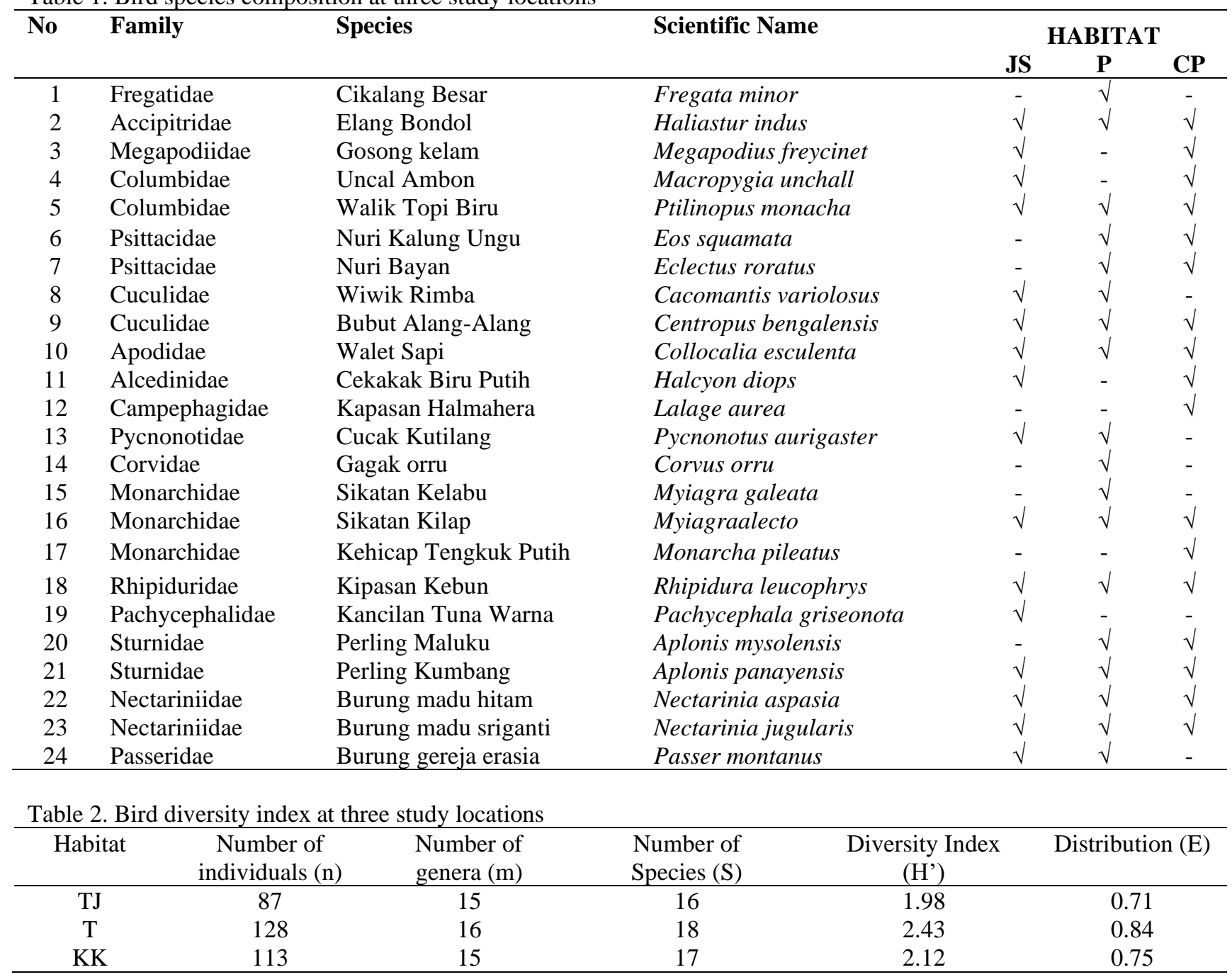

Description: JS=Jamblang Stand, $\mathrm{P}=$ Periphery, $\mathrm{CP}=$ Coconut Plantation

In contrast to periphery habitat, the vegetation structure in coconut plantation habitats and jamblang stands tended to be homogeneous, so it affected the diversity of bird species. According to Simanjuntak et al., (2013), gardens are new forms of habitat after natural forests are transformed into plantation forests or plantations, where heterogeneous communities turn into homogeneous vegetation. Kaban (2013) showed that bird diversity in pine and agathis stands in Gunung Walat Educational Forest (HPGW) is lower when compared to bird diversity in peripheral habitats in HPGW and mixed gardens in the Mbeliling Barat Landscape of Flores (Tamnge, 2016; Hamzati and Aunurohim, 2013). Hanzelka and Reif, 2016) suggest that bird species richness increases significantly as the increasing diversity of vegetation types. Furthermore, Desmukh (1992) states that diversity becomes greater if the abundances of the population is evenly distributed.

Various types of habitats, such as plantations, yards, secondary forests, primary forests, and open land/shrubs are habitats for various types of birds. In general, bird habitats are divided into land, fresh water and sea, and can be further divided according to its plants, such as dense forests, shrubs, and grasses (Rusmendro, 2009). Several types of birds can use various types of habitats to find food, breed, and maintain their survival. The bird species identified in all study locations were red-backed sea-eagle (Haliastur indus), willie wagtail (Rhipidura leucophrys), and yellow-bellied sunbird (Nectarinia jugularis). According to Coates and Bishop (2000), These three types of birds are common settlers that are often found around the coast as well as land, forest edges, sometimes in mountain forests, often visiting villages, small towns, grassy areas, coconut plantations and urban parks.

Meanwhile, the specialist type that was only found in each location was Toressian crow (Corvus orru) in the peripheral area, drab whistler (Pachycephala griseonota) in Jamblang Stands and rufous-bellied triller (Lalage aurea) in coconut plantations. According to Coates and 
Bishop (2000), C. orru can be found in open areas, on the coast around rural and urban areas. L. aurea is endemic to North Maluku which is quite common in inhabiting open secondary forests and shrubs, primary forests and selectively logged forests, while $P$. griseonota is endemic to the Sula and Maluku Islands and quite commonly found in the lowlands, cultivated land with few trees, and shrubs. Hasan (2017) suggests that the composition of bird species is influenced by differences in habitat conditions. Birds will live in habitats that can meet their daily needs such as eating, drinking, resting, and breeding.

Pearson Index analysis showed that bird diversity was not correlated with arthropod abundance $(\mathrm{r}=0.003$, $\mathrm{p}>0.05$ ). After checking the bird guilds at the study location, 11 bird species were found to be insectivorous, while the remaining 13 species were birds that eat other birds; 7 species were fruit-eating birds, 2 species were nectarivores, and each 1 species was omnivorous bird, carnivore and scavenger, a type of seabird, and was categorized as other bird groups (Figure 2). The results of this study are different compared to the study by Yeni et al. (2020) in Sukabumi HPGW, where more species of insectivorous birds were identified as many as 24 species.

According to O Connell et al. (2000) and Karr (1980), guild is a group of species that use the same resources and in the same way. A group of species can be said to have the same guild based on the way they obtain resources, such as food resources. The diverse habitats around the study location are able to support a variety of bird guilds ( 7 types of guilds). The variation in the types of guilds indicates that the surrounding areas of the study, that are jamblang stands, coconut plantations and peripheral areas are habitable for various types of birds. The bird guilds around the study location are influenced by how the birds obtain food and the available resources.

\section{Arthropod Community}

Based on the observation, 13 families from 10 arthropod orders were found in the three study locations. There were 10 arthropod orders found in the three study locations. Peripheral habitat was the study location with the highest number of orders found compared to other habitats (JS: 5 orders; P: 10 orders; CP: 9 orders) (Figure 2). The results of identification using yellow traps showed that Lepidoptera, Hymenoptera, and Diptera were abundant orders at the three study locations. This is in accordance with Prawiradilaga (1990) who states that the three orders are the main groups of arthropod orders that are preyed upon by more than 100 bird species.

In general, Lepidoptera order found at the study locations has two pairs of wings covered with minutes' scales and attractive colors like butterflies and moths. The Hymenoptera order generally has two pairs of wings, thin like a membrane, for example ants and bees, while the Diptera order is a type of insect that only has one pair of front wings because the rear pair of wings has evolved into a sphere called as halteres. These wings are functioned to balance the birds when flying, to find direction, and also functioned as hearing sensors, for example in the types of fruit flies and mosquitoes.

Based on the study, the number of insect families found in the peripheral habitat was higher, which was 13 families when compared to jamblang stands and coconut plantations which were only consisted of 8 families (Table 3). This is in accordance with the research of Mulyani et al. (2020) which showed that the presence of insects is abundant in the peripheral habitat compared to the interior habitat. Peripheral areas are usually surrounded by low-biomass matrix such as grassland and young secondary growth, causing variations in temperature and humidity as well as light intensity. According to Murcia (1995), differences in the complexity of the structure and biomass lead to differences in microclimate. The sun intensity around the peripheral habitat tends to be higher which attracts insects. These insects are attracted to light because light serves as a direction guide for them.

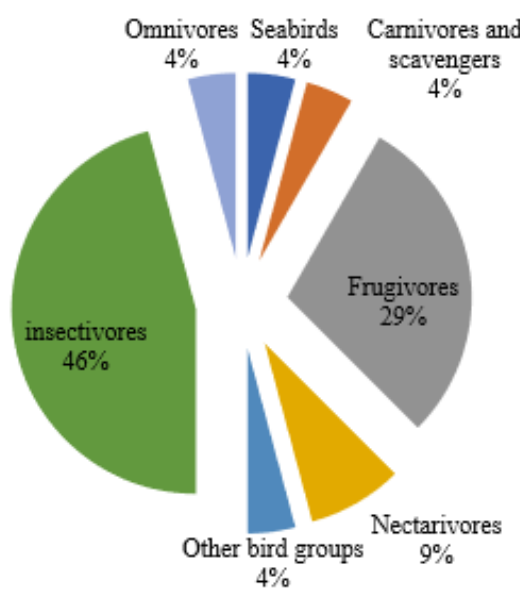

Figure 2. Percentage of bird guilds in fragmented habitat 


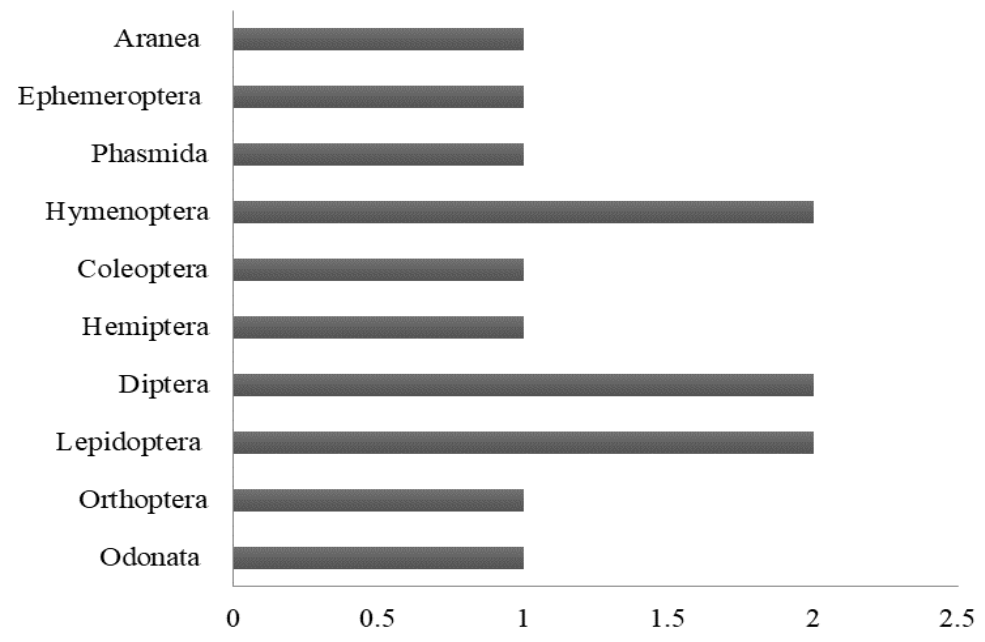

Figure 3. Number of genera in each identified arthropod order

Table 3. Number of insect families found at three observation locations

\begin{tabular}{clccc}
\hline No & Family & Jamblang Stands & Periphery & Coconut plantations \\
\hline 1 & Libelluidae & - & $\sqrt{ }$ & $\sqrt{ }$ \\
2 & Acrididae & $\sqrt{ }$ & $\sqrt{ }$ & - \\
3 & Nympalidae & $\sqrt{ }$ & $\sqrt{ }$ & $\sqrt{ }$ \\
4 & Geometridae & $\sqrt{ }$ & $\sqrt{ }$ & $\sqrt{ }$ \\
5 & Tephritidae & $\sqrt{ }$ & $\sqrt{ }$ & $-\sqrt{ }$ \\
6 & Culicidae & $\sqrt{ }$ & $\sqrt{ }$ & - \\
7 & Formicidae & $\sqrt{ }$ & $\sqrt{ }$ & - \\
8 & Plataspididae & - & $\sqrt{ }$ & - \\
9 & Gyrinidae & $\sqrt{ }$ & $\sqrt{ }$ \\
10 & Diapheromeridae & - & $\sqrt{ }$ & - \\
11 & Agelenidae & Triplosobidae & - & $\sqrt{ }$ \\
\hline
\end{tabular}

\section{CONCLUSION}

The results of the study found that the abundance and diversity are different between the peripheral and interior habitats (jamblang stands and coconut plantation). The peripheral area is the location with the highest abundance and diversity. There is no correlation between abundance of arthropod and birds. It is becuase the low number of insectivorous birds identified at the study location.

\section{REFERENCES}

Arumasari. 1989. Komunitas burung pada berbagai tipe habitat di kampus UI, Depok. Skripsi. Universitas Indonesia. Depok.

Berry L. 2001. Edge effect on the distribution and abundance of birds in A Southern Victorian Forest. Wildlife Research 28: 239-245.
Bibby C, Jones M, Marsden S. 2000. Expedition Field Techniques Birds Surveys. Expedition Advisor Centre. London.

Chan, Crosby MJ, Islam MZ, Tordoff AW. 2004. Important Bird Areas in Asia: Key sites for Conservation. BirdLife International. Retrieved from www.birdlife.org/datazone/info/ibasasia [10 Agustus 2019]

Coates BJ, Bishop KD. 2000. Panduan Lapang BurungBurung di Kawasan Wallacea: Sulawesi, Maluku, dan Nusa Tenggara. BirdLife International-Indonesia Programme. Jakarta.

Desmukh I. 1992. Ekologi dan Biologi Tropika. Yayasan Obor Indonesia. Jakarta

Hamzati Nn n n S, Aunurohim. 2013. Keanekaragaman Burung di Beberapa Tipe Habitat di Bentang Alam Mbeliling Bagian Barat, Flores. Jurnal Sains dan Seni Pomits 2 (2): 121-126.

Hanzelka J, Reif J. 2016. Effects of Vegetatation Structure on The Diversity of Breeding Bird Communities in Forest Stands of Non-Native Black Pine (Pinus nigra A.) and Black Locust (Robinia 
pseudoacacia L.) in The Czech Republic. Forest Ecology and Management 379 (1): 102-113.

Hasan M. 2017. Keanekaragaman Jenis Burung di BeberapaTipe Habitat di Hutan Penelitian Haurbentes Jasinga Kabupaten Bogor Jawa Barat. Skripsi. Institut Pertanian Bogor. Bogor.

Kaban A. 2013. Keanekaragaman Jenis Burung pada Beberapa Tipe Tegakan di Hutan Pendidikan Gunung Walat, Sukabumi Jawa Barat. Skripsi. Institut Pertanian Bogor. Bogor.

Karr JR. 1980. Geographical variation in the avifaunas of tropical forest undergrowth. Auk. 97: 283-298.

Magurran AE. 2004.Measuring Biological Diversity. Blackwell. Oxford.

Mardiastuti A. 2015. Ekologi Satwa pada Lanskap yang Didominasi Manusia. Fakultas Kehutanan IPB ? Bogor.

Meffe GK, Carol CR. 1994. Principle of Conservation Biology. Sinnauer Associate, Inc. Sunderland.

Mulyani YA, Haneda NF, Purnomo H, Kaban A. 2020. Insectivorous Birds in Edge and Interior Habitat of Forest Plantation in GunungWalat, Sukabumi, 1-7. IOP Conference Series: Earth and Environment Science. IOP Publishing. Bogor.

Murcia C. 1995. Edge effects in fragmented forests: implication for conservation. TREE. 10 (2): 58-62.

O' Connell TJ, Jackson LE, Brook RP. 2000. Bird guilds as indicators of ecological condition in the central Appalachians. Ecological Application 10 (6): 17061721.
Prawiradilaga DM. 1990. Potensi burung dalam pengendalian populasi serangga hama. Media Konservasi 3 (1): 1-7.

Rombang WM, Rudyanto. 1999. Daerah Penting Bagi Burung Jawa dan Bali. PKA/BirdLife InternationalIndonesia Programme. Bogor.

Rusmendro H. 2009. Perbandingan Keanekaragaman Burung pada Pagi dan Sore Hari di Empat Tipe Habitat di Wilayah Pangandaran, Jawa Barat. VIS VITALIS. 2 (1): 8-16.

Simanjuntak EJ, Nurdjali B, Siahaan S. Keanekaragaman Jenis Burung Diurnal di Perkebunan KelapaSawit PTPN XIII Persero Desa Amboyo Inti Kecamatan Ngabang Kabupaten Landak. Jurnal Hutan Lestari 1 (3) : 317-326.

Sulthoni A, Subyanto, Christina LS, Sri SS. 1991. Kunci Determinasi Serangga Program Nasional Pelatihan dan Pengembangan Pengendalian Hama Terpadu. Kanisius. Yogyakarta.

Sukmantoro W. Irham M, Novariono W, Hasudungan F, Kemp N, Muchtar M. 2007. Daftar Burung Indonesia No. 2. Indonesian Ornithologist' Union. Bogor.

Tamnge F. 2016. Ekoton dan Efek Tepi pada Komunitas Burung di Tegakan Hutan Tanaman Hutan Pendidikan Gunung Walat. Tesis. Institut Pertanian Bogor. Bogor.

Yoza D. 2006. Keanekaragaman jenis burung di berbagai tipe daerah tepi (edges) Taman Hutan Raya Sultan Syarif Hasyim Propinsi Riau [Tesis]. Bogor: Sekolah Pascasarjana Institut Pertanian Bogor. 